\title{
AN INVITATION TO MEXICAN COURTS TO ENGAGE WITH TRANSNATIONAL SOURCES OF LAW
}

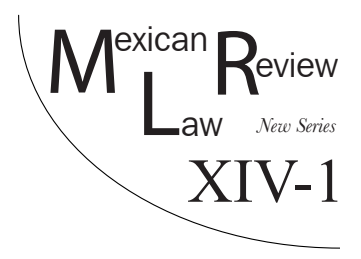

\author{
Zulima GonZÁLEZ*
}

\begin{abstract}
In 2009, Mexican Courts started to engage in a transnational conversation between foreign courts. After Mexico was sentenced by the InterAmerican Court of Human Rights (IACHR) in the case of Radilla Pacheco, the Mexican Supreme Court determined, among other things, that all national judges must examine the human rights interpretations issued by the Federal Fudiciary and the IACHR, choosing the most favorable and effective interpretation to protect human rights, applying the pro homine principle. Nonetheless, nothing has been said about using case law from foreign courts as persuasive authority to find this "most favorable and effective interpretation of human rights" in Mexico. This article analyses whether Mexican courts should take into account the interpretations of foreign courts as persuasive authority when determining standards and scope of human rights, besides IACHR case law. I evaluate different theories that support the use and citation of foreign precedents, as well as arguments that raise concerns about citing foreign courts to interpret domestic legal frameworks. I conclude that, in order to make use of the most effective principles and standards of human rights, as the pro persona principle suggest,

Mexican Courts should consider foreign case law.
\end{abstract}

Keywords: Human Rights, case law, sources of law, persuasive authority, pro persona principle.

RESUMEN: En el año de 2009 los tribunales mexicanos comenzaron a participar en la conversación trasnacional que existe entre tribunales extranjeros. Después de que México fue sentenciado por la Corte Interamericana de Derechos Humanos (CIDH) en el caso Radilla Pacheco, la Suprema Corte de Justicia de la Nación determinó, entre otras cosas, que todos los jueces nacionales deben examinar las interpretaciones de derechos humanos emitidas tanto por el Poder Fudicial de la Federación como por la CIDH, eligiendo la interpretación más favorable y efectiva para la protección de derechos humanos, aplicando el principio pro persona. No

* LLM in Human Rights. Partner at Pérez Correa, González y Asociados, S.C. Email: zgonzalez@pcga.mx. 
obstante, nada ha sido establecido en México sobre el uso de la jurisprudencia establecida por tribunales extranjeros como autoridad persuasiva para encontrar esta interpretación más favorable y efectiva sobre derechos humanos. Este artículo analiza si los tribunales mexicanos deberian tomar en consideración, además de la jurisprudencia de la CIDH, las interpretaciones de tribunales extranjeros, como autoridad persuasiva, al determinar los estándares y alcance de los derechos humanos; lo anterior evaluando distintas teorías que apoyan el uso de precedentes extranjeros, así como aquellos argumentos que señalan preocupaciones sobre citar a tribunales extranjeros para interpretar el derecho interno. Al finalizar, concluyo que, con el objeto de aplicar los principios y estándares más eficientes de derechos humanos, como lo sugiere el principio pro persona, los tribunales mexicanos deben considerar la jurisprudencia extranjero al interpretar dichos derechos.

Palabras clave: Derechos Humanos, jurisprudencia, fuentes de derecho, autoridad persuasiva, principio pro persona.

\section{Table of Contents}

I. INTRODUCTION

II. The Opening-up of Mexican Courts to the Transnational

Dialogue

1. IACHR Conventionality Control Doctrine 94

2. The Pro Homine or Pro Persona Principle.................................. 95

3. Facts of the Radilla Pacheco Case and the IACHR Decision....... 97

4. The Incorporation of the Conventionality Control Doctrine and the Pro Persona Principle in Mexico.

A. Amendment of the Mexican Constitution .............................. 98

B. The Decision in the Varios 912/2010 File ................................ 98

C. The Decision in File 293/201 1.............................................. 100

III. The Gurrent Use of Foreign Courts' Case Law by Mexican CourTs

IV. The Use of Foreign Human Rights Interpretations

to Enforce the Pro Persona Principle

V. Reasons to Consider Foreign Case Law as Persuasive

Authority .....

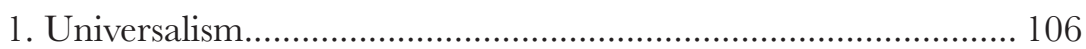

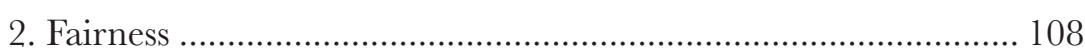

3. Ius Gentium .................................................................. 108

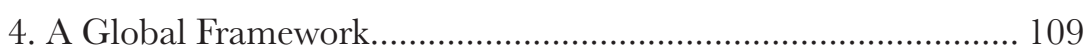

5. Persuasiveness or Legitimacy ................................................ 110

6. Text Similarities .................................................................... 111

7. Law as an Inquiry ..................................................................... 111 
8. Constitutional Law as Mediating the Domestic and the Global.... 112

9. Pedagogical Impulse and Pragmatism ...................................... 112

10. Existence of Common Alliances............................................... 113

VI. Responding to Counterarguments .......................................... 114

1. Constitutions are Self-Constituting and Self-Expressive............. 114

2. Originalism and Popular Sovereignty ...................................... 115

3. It is Anti-democratic ........................................................ 116

4. Cherry-picking ................................................................. 117

5. Lack of Understanding.......................................................... 118

6. Cultural Elites............................................................................. 119

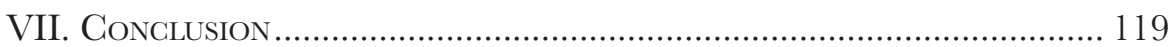

\section{INTRODUCTION}

Since the end of World War II, there has been an ongoing development of human rights protections at international and regional levels. Most countries have signed and ratified human rights charters and treaties, such as the Universal Declaration of Human Rights, the International Covenant on Civil and Political Rights and the International Covenant on Economic, Social, and Cultural Rights. Furthermore, supranational human rights courts have been established, and several international organizations and bodies have been created to promote, implement, and protect human rights. The proliferation of human rights law has also taken place within national legal systems, where States have adopted legislation to deal with abuses, drafted bills of rights, or even applied and incorporated international and regional human rights law into their domestic legislation. ${ }^{1}$ Along with the legal development of human rights, legal methods of dispute resolution and interpretation have been used as an essential tool to protect and further these legally-based human rights values. ${ }^{2}$

In the last few decades, we have witnessed the Supreme Court of the United States recognize women's right to decide whether to have an abortion, ${ }^{3}$ the Constitutional Court of South Africa declare that the State must devise and implement a program to satisfy the right of access to adequate housing, ${ }^{4}$ the Supreme Court of Canada strike down a ban on wearing a Sikh kirpan to school as it violated freedom of religion, ${ }^{5}$ and so on.

1 Christopher McCrudden, Common Law of Human Rights?: Transnational fudicial Conversations on Constitutional Rights, 20 Oxford Journal of Legal Studies 499-532, 500 (2004).

2 Ibid. at 500.

3 Roe $v$. Wade, 410 U.S. 113 (1973) (U.S.A.).

4 South Africa v. Grootboom, 2001 (1) SA 46 (South Africa).

5 Multani v. Commission Scolaire Marguerite-Bourgeoys (2006) 1 SCR 256. 167 (Canada). 
Nonetheless, for decades, the Mexican courts, like other Latin American courts, did not engage in this constitutional interpretation of human rights. ${ }^{6}$ Until recently, there were no judgments dealing with the rights to freedom of expression, non-discrimination, education, health, and housing, among other issues. ${ }^{7}$ Mexican courts only began to use modern techniques of constitutional interpretation, acknowledging their role as guarantors of human rights in the last decade of the twentieth century. ${ }^{8}$

Moreover, as I explain further on, in 2009 after the Inter-American Court of Human Rights (IACHR) ruling in the case of Radilla Pacheco, Mexico took another step forward in the protection of human rights. The Mexican constitution was amended in order to adjust the hierarchy of international human rights law and the pro persona principle was introduced. This principle sets two interpretative rules for Mexican authorities: $i$ ) human rights provisions norms must be interpreted in the most extensive way possible and human rights limitations in the least restrictive way possible, and ii) if there is a conflict or clash between different human rights provisions, either the more protective one or less restrictive one must be adopted. ${ }^{9}$

Furthermore, when the Mexican Supreme Court discussed how the judicial power in Mexico should fulfil the judgment of the mentioned case, the Court, among other things, determined that all national judges must enact a "conventionality control". Thus, they must try to harmonize national provisions with the Constitution and the human rights treaties ratified by Mexico. ${ }^{10}$ Additionally, they must examine national human rights interpretations issued by the Federal Judiciary and IACHR, choosing the most favorable and effective interpretation to protect human rights, applying the pro homine principle. ${ }^{11}$

Accordingly, the acceptance of the conventionality control by Mexico opened its courts to participate in the transjudicial dialogue of human rights. However, the understanding of such dialogue has been quite limited, as judicial interpretations of human rights provisions in other jurisdictions have been ignored as a source of judicial authority in the interpretation of human rights.

6 Jorge Alejandro Amaya, La Interpretación Constitucional de los Derechos Fundamentales y el Uso del Derecho Comparado, 12 LEX-Revista de la Facultad de Derecho y Giencias Políticas 55-71, 65-66 (2014); Miguel Carbonell, La Interpretación Constitucional de Los Derechos Fundamentales y El Uso Del Derecho Comparado En El Diálogo Furisprudencial, in Diálogo Jurispruencial en Derechos Humanos entre Tribunales Constitucionales y Cortes Internacionales 601 (Eduardo Ferrer Mac-Gregor and Alfonso Herrera eds. Tirant lo Blanch, 2013).

7 Carbonell, supra note 6, at 601 .

8 Ibid. at 601-602.

9 Valerio de Oliveira Mazzuoli, The Pro Homine principle as a fundamental aspect of International Human Rights Law, 47 Journal of Global Studies 1-9, 5 (2016).

10 Suprema Corte de Justicia de la Nación [S.C.J.N.] [Supreme Court], Exp. Varios 912/2010 (Méx.).

11 Id. 
Consequently, in this article I argue that Mexican courts should not only examine national interpretations and IACHR's case law when interpreting human rights, as the conventionality control doctrine suggests, but they should also engage with foreign human rights case law, as persuasive authority, in order to look for the most beneficial standard for human rights protection or the least restrictive limitation to such rights, as required by the pro persona principle.

Before moving forward, it is important to mention that by "Mexican courts" I am referring to all national judges in the United Mexican States, both from the federal judicial branch and the local courts in each of the thirty-two states. Further, by "foreign courts" I mean apex courts from other liberal democratic regimes, as these countries are the ones which have participated in the expansion of human rights and, according to Slaughter, are those States which have "some form of representative government secured by the separation of powers, constitutional guarantees of civil and political rights, juridical equality, and a functioning judicial system dedicated to the rule of law". ${ }^{12}$ Also, as McCrudden found "in the main, it is the judiciaries of liberal democratic regimes that cite each other". ${ }^{13}$

Finally, for the purpose of this article, "human rights" are the goods, services, opportunities, and protections that all humans are entitled to for a life of dignity and the set of practices or conditions for their supply. ${ }^{14}$

The article is organized as follows. In Section II, I justify my claim by explaining the development of the opening-up of the Mexican courts to the transnational dialogue by describing the implications of the conventionality control doctrine and the pro persona principle. Furthermore, I describe the process of the adoption of both the conventionality control doctrine and the pro persona principle by Mexican courts. In Section III, I analyze the current use of foreign case law for the interpretation of human rights in Mexico. In Section IV I argue that in order to enforce the pro homine principle in the best possible way, Mexican courts should take into account, as persuasive authority, foreign courts' interpretations about human rights, engaging with them when they are more favorable or less restrictive than domestic precedents or IACHR's case law. In Section V, I evaluate the reasons for engaging with foreign human rights case law when looking for the most favorable or least restrictive interpretation of human rights. In Section VI, I consider several counterarguments to my claim. Finally, in Section VII I conclude that Mexican courts should acknowledge foreign courts' interpretations when looking for human rights principles and standards, as it is compatible with the understanding of human rights law within its legal system while restricting their

12 Anne-Marie Slaughter, International Law in a World of Liberal States, 6 EuropeAn JournaL OF INTERNATIONAL LAW 503-538, 511 (1995).

13 McCrudden, supra note 1 , at 518.

14 Jack Donnelly, Toward a Theory of Human Rights, 3 Universal Human Rights in TheOrY and Practice 7-23, 17 (2013). 
analysis only to domestic interpretations and IACHR case law, only enforcing the conventionality control, can limit the protection of human rights.

\section{The Opening-up of Mexican Courts to the Transnational Dialogue}

After the IACHR judgment in the case of Radilla Pacheco on June 10, 2011, the Mexican constitution was amended to adjust the hierarchy of international human rights law in Mexico's legal system. In consequence, a new notion of human rights was introduced, as well as a new requirement for their interpretation, the pro persona principle. Moreover, Mexican courts accepted IACHR conventionality control doctrine, thus, they opened to participate in the transnational judicial dialogue taking place around the world.

\section{IACHR Conventionality Control Doctrine}

Despite the fact that the IACHR is the primary body in charge of interpreting the American Convention of Human Rights, it has formulated the conventionality control doctrine for judges in the Inter-American system to apply international rules and standards when interpreting human rights within their spheres of competence. ${ }^{15}$ This doctrine requires national judges to attempt a harmonization between domestic legislation and the American Convention on Human Rights. ${ }^{16}$ Additionally, it mandates that if domestic legislation differs from what the American Convention on Human Rights states, judges shall give preference to the latter, as they are bound by it, as well as by IACHR interpretations. ${ }^{17}$

The conventionality control doctrine is not found in the text of the American Convention on Human Rights. The IACHR first formulated it on September 26, 2011, when deciding the case Almonacid Arellano v. Chile, in which the Court found Chile to be responsible for violating Luis Alfredo Almonacid Arellano's rights when enacting and enforcing amnesty laws in favor of the policemen who executed him in 1973 during the Pinochet regime. The Court determined the following:

124. The Court is aware that domestic judges and courts are bound to respect the rule of law, and therefore, they are bound to apply the provisions in force

15 Jorge Contesse, The international authority of the Inter-American Court of Human Rights: A critique of the conventionality control doctrine, 22 InTERnATIONAL JOURnal OF Human Rights 1168-1191, 1170 (2017).

16 Max Silva Abbot, Internal Control of Conventionality And Local Judges : A Faulty Approach, 14 Estudios Constitucionales 1-18, 2 (2016).

17 Contesse, supra note 15, at 1170. 
within the legal system. But when a State has ratified an international treaty such as the American Convention, its judges, as part of the State, are also bound by such Convention. This forces them to see that all the effects of the provisions embodied in the Convention are not adversely affected by the enforcement of laws which are contrary to its purpose and that have not had any legal effects since their inception. In other words, the Judiciary must exercise a sort of "conventionality control" between the domestic legal provisions which are applied to specific cases and the American Convention on Human Rights. To perform this task, the Judiciary has to take into account not only the treaty, but also the interpretation thereof made by the Inter-American Court, which is the ultimate interpreter of the American Convention. ${ }^{18}$

Hence, the IACHR established that when a State ratifies the American Convention on Human Rights, their judges are obliged to consider it and discard any domestic legislation that may be contrary to its object and purpose. Thus, they must enact a "conventionality control" among domestic legislation and the Convention, as well as to apply IACHR interpretations of the Convention.

The conventionality control doctrine seeks a jurisprudential dialogue between the IACHR and the domestic courts of the States under its jurisdiction. ${ }^{19}$ The IACHR expects national courts to be the first Inter-American judges and for them to harmonize domestic legislation with the standards of the Inter-American system as the "primary and authentic guardians" of the American Convention on Human Rights. ${ }^{20}$

The IACHR has found this dialogue to be very valuable as it has enhanced human rights protection in the region and has even helped develop to the Court's case law. ${ }^{21}$ Nonetheless, the role of national judges introduced by the IACHR has not been received in the same way by all States, whereas countries like Brazil and Venezuela have not welcomed this doctrine, as I mentioned, Mexico has adopted it as a rule for the interpretation of human rights. ${ }^{22}$

\section{The Pro Homine or Pro Persona Principle}

The pro homine or pro persona principle originated in Latin America through the IACHR interpretation of Article 29 (b) of the American Convention on

18 Almonacid Arellano v. Chile Case, 2006 Inter-Am. Ct.H.R. (Ser. G) No. 154, at 124 (Sept. 26, 2006).

19 Eduardo Ferrer Mac-Gregor, Interpretación conforme y control difuso de convencionalidad. El nuevo paradigma para el juez mexicano, 9 Estudios Constitucionales 531-622, 618 (2011).

20 Ibid. at 620; Yota Negishi, The Pro Homine Principle's Role in Regulating the Relationship Between Conventionality Control and Constitutionality Control, 28 European Journal of International LaW 457-481, 458 (2017).

21 Ferrer Mac-Gregor, supra note 19, at 618.

22 Laurence Burgorgue-Larsen, Context, Techniques and Effects of the Interpretation of the American Convention of Human Rights, 12 Estudios Constitucionales, 105-161, 134-135 (2014). 
Human Rights, ${ }^{23}$ which expresses that "no provision of the Convention shall be interpreted as restricting to the enjoyment or exercise of any right or freedom recognized by virtue of the laws of any State Party or by virtue of another convention to which one of the States is a party". ${ }^{24}$

In Advisory Opinion OC-1/82 of September 24, 1982, the IACHR considered that, when interpreting human rights, the Court must not exclude other international human rights treaties that are binding to the American States, as it would weaken the full guarantee of rights and would enter into conflict with Article 29 (b) of the American Convention of Human Rights. ${ }^{25}$

Later on, in Advisory Opinion OC-5/85 of November 13, 1985, the Court stated that since Article 29 (b) indicates that no provision of the Convention may be interpreted as restricting the enjoyment or exercise of any right or freedom. Then, if the same situation arises and both the American Convention and another international treaty are applicable, the rule that is more favorable to the individual must prevail. ${ }^{26}$

In this regard, the interpretation principle called pro persona is a "hermeneutic criterion", which implies that the broader rule or interpretation must prevail when recognizing individuals human rights, and inversely, when imposing limits to human rights, the less restrictive rule or interpretation must be preferred. ${ }^{27}$ Just as in other areas of law we find similar principles such as favor debitoris in civil law, in dubio pro reo in criminal law and in dubio pro operario in labor law, the pro homine principle looks to even out the inequalities between the individual and the State, when the former exercises his or her human rights. ${ }^{28}$

Consequently, the interpretation that optimizes the fundamental right, either because it amplifies the scope of protected subjects or the scope of protection of the right, must be preferred over other available interpretations. ${ }^{29}$ Thus, the interpreter is not free to choose the rule or interpretation

23 Alejandro Rodiles, The Law and Politics of the Pro Persona Principle in Latin America, 1 THE Interpretation of International Law by Domestic Courts: Uniformity, Diversity, ConVERGENCE 153-174, 162.

24 Article 29 (b) of the American Convention on Human Rights.

25 IACHR. Advisory Opinion OC-1/82 Of September 24, 1982. "Other Treaties " Subject to The Consultative Jurisdiction of the Court (Article 64 American Convention on Human Rights).

26 IACHR. Advisory Opinion OC-5/85, November 13, 1985. Compulsory Membership in An Association Prescribed by Law for The Practice of Journalism (Articles 13 and 29 American Convention on Human Rights).

27 Monica Pinto, El principio pro homine. criterios de hermenéutica y pautas para la regulacion de los derechos humanos (July 24, 2020), available at http://repositoriocdpd.net:8080/bitstream/handle/123456789/594/CL_PintoM_PrincipioProHomine_1997.pdf? sequence=1.

28 Humberto Henderson, Los tratados internacionales de derechos humanos en el orden interno: la importancia del principio pro homine, 39 REVISTA IIDH 71-100, 91-92 (2005).

29 Carbonell, supra note 6, at 605-606. 
they wish, as they must choose the one that best protects the human right in question, regardless of the hierarchy that applicable rules have within a country's legal order. ${ }^{30}$

The concrete and substantial parameters to comply with the constitutional mandate for the interpretation and application of the pro persona principle are yet to be fully determined. However, as Gerardo Mata claims, in order to choose which rule or interpretation must be chosen when applying the pro persona principle, courts should opt for the one that protects the greatest number of people, for the longest period of time and in the best possible way. ${ }^{31}$

\section{Facts of the Radilla Pacheco Case and the LACHR Decision}

In August 1974, Rosendo Radilla Pacheco was arrested and presumably disappeared by members of the Mexican Army in the state of Guerrero. Radilla's daughters filed four criminal complaints regarding the forced disappearance of their father, all of which were unsuccessful in finding him or identifying, prosecuting, or punishing those responsible for his disappearance. ${ }^{32}$

On 2001, Mr. Radilla's case was presented to the Inter-American Commission on Human Rights, which determined that Mexico had violated the rights of Mr. Radilla and his family, and eventually submitted the case to the IACHR. ${ }^{33}$

The IACHR determined that Mexico violated multiple articles of the Inter-American Convention by failing to conduct an effective and diligent investigation of Mr. Radilla's arrest and subsequent disappearance, as well as to effectively investigate, identify, prosecute and punish the responsible parties. ${ }^{34}$ Particularly, by applying military jurisdiction to the case which involved a forced disappearance, the State infringed Mr. Radilla's next of kin's right to a competent court and deprived her of effective recourses to contest his arrest and disappearance. ${ }^{35}$

The Court claimed that, as it had mentioned before, domestic judges shall exercise a conventionality control, thus take into consideration the American Convention of Human Rights and IACHR case law when inter-

30 Ibid. at 606.

31 Gerardo Mata, La Interpretación Conforme En El Sistema Constitucional Mexicano, 46 Revista del Instituto de la Judicatura Federal, 213-247, 235-236 (2018); Gerardo Mata, El principio pro persona: la fórmula del mejor derecho, 39 Revista Mexicana de Derecho ConSTITUCIONAL 201-228, 211 (2018).

32 Radilla-Pacheco v. Mexico, Inter-Am. Ct.H.R., 2009 (Ser. C) No 209 (November 23, 2009).

33 Id.

34 Id.

35 Id. 
preting national rules; therefore, the competence criteria of military jurisdiction in Mexico should be adjusted to correspond with the principles established in IACHR case law. ${ }^{36}$ Moreover, the Court declared that Mexico had to reform its Military Criminal Code, in a reasonable period of time, in order to make it compatible with the international standards of the field and the American Convention of Human Rights. ${ }^{37}$

\section{The Incorporation of the Conventionality Control Doctrine and the Pro Persona Principle in Mexico}

\section{A. Amendment of the Mexican Constitution}

As mentioned, after the ruling on the case of Radilla Pacheco, the Mexican constitution was reformed, ushering in a new appreciation of human rights law. Article 1 now declares the following:

In the United Mexican States, all individuals shall be entitled to the human rights granted by this Constitution and the international treaties signed by the Mexican State, as well as to the guarantees for the protection of these rights. Such human rights shall not be restricted or suspended, except for the cases and under the conditions established by this Constitution itself. ${ }^{38}$

The provisions relating to human rights shall be interpreted according to this Constitution and the international treaties on the subject, working in favor of the broader protection of people at all times. ${ }^{39}$

All authorities, in their areas of competence, are obliged to promote, respect, protect, and guarantee Human Rights, in accordance with the principles of universality, interdependence, indivisibility and progressiveness. As a consequence, the State must prevent, investigate, penalize, and rectify violations to Human Rights, according to the law. ${ }^{40}$

\section{B. The Decision in the Varios 912/2010 File}

The amendment of the Constitution, as well as its scope and importance, was interpreted by the Supreme Court in the resolution of the "Varios 912/2010" file, where the Mexican Supreme Court analyzed the role of the Federal Judiciary in the enforcement of the judgment issued in the case of Radilla Pacheco.

\footnotetext{
36 Id.

37 Id.

38 Constitución Política de los Estados Unidos Mexicanos [Const.], as amended, Diario Oftcial de la Federación [D.O.F], February 5, 1917 (Mex.).

39 Id.

40 Id.
} 
The Supreme Court concluded, among other things, that the Supreme Court cannot review, analyze, or decide whether an IACHR judgment is correct or appropriate.$^{41}$ Moreover, the judgments issued by IACHR in cases where the Mexican State is one of the parties are binding, regarding both the final decision and the merits such resolutions may contain. According to the Supreme Court, this interpretation follows the fact that in the dispute before the IACHR, the Mexican State has the opportunity to participate and defend itself against the victim's claims. ${ }^{42}$ Besides, Mexico has accepted IACHR jurisdiction under the terms stated in Articles 62.3, 67, and 68 of the American Convention of Human Rights, committing to comply with its decisions. ${ }^{43}$

Moreover, the Supreme Court decided that the IACHR case law dictated in cases where the Mexican State was not a party is not binding but must be considered as guiding when the standards and scope of human rights protection it establishes are broader and more favorable to the person than those established by the Mexican Judiciary. ${ }^{44}$

Besides, one of the primary obligations arising from the Radilla Pacheco case for Mexican Judicial Federal Power is that all judges must thereafter enact the conventionality control, between national legislation and the American Convention on Human Rights, within their constitutional power. ${ }^{45}$ The Supreme Court declared that this obligation is consistent with the amendment to Article 1 of the Constitution, which mandates that all authorities are obliged to protect the human rights contained in the Constitution and the international human rights treaties to which the Mexican State is a party, choosing the most favorable interpretation, as the doctrine known as the pro persona principle suggests. ${ }^{46}$

Finally, the Supreme Court reinterpreted Article 133 of the Constitution, ${ }^{47}$ in order to harmonize it with the amendment of Article 1. Consequently, the Supreme Court declared that, when interpreting human rights issues, all judges must avoid applying unconstitutional or unconventional national laws. ${ }^{48}$ Nonetheless, not all courts are empowered to make a general declara-

41 Suprema Corte de Justicia de la Nación [S.C.J.N.] [Supreme Court], Exp. Varios 912/2010 (Mex.).

$42 I d$.

$43 \mathrm{Id}$.

$44 \mathrm{Id}$.

45 Id.

46 Id.

47 Article 133 of the Political Constitution of the United Mexican States declares: "This Constitution, the laws derived from and enacted by the Congress of the Union, and all the treaties made and executed by the President of the Republic, with the approval of the Senate, shall be the supreme law of the country. The judges of each state shall observe the Constitution, the laws derived from it and the treaties, despite any contradictory provision that may appear in the constitutions or laws of the states", available at https://wrerw2.juridicas.unam.mx/ constitucion-reordenada-consolidada/en/vigente.

$48 \mathrm{Id}$. 
tion about such unconstitutionality or strike down unconstitutional provisions since such power is reserved only for the Federal Judicial Power under the terms of the Constitution. ${ }^{49}$

\section{The Decision in File 293/2011}

Later on, in the "Contradicción de Tesis 293/2011" file, when deciding between contradicting interpretations issued by two Federal Courts regarding the hierarchy of international human rights law in Mexico's legal system, as well as the conventionality control doctrine scope and the obligatory nature of IACHR case law, the Supreme Court resolved that the human rights contained in the Constitution and international human rights treaties form a "constitutional regularity control" for domestic laws. ${ }^{50}$ Nonetheless, if there is an express restriction in the Constitution, such restriction must be applied even if there is a more protective provision in an international human rights treaty. ${ }^{51}$

Most importantly, the Supreme Court determined that IACHR case law is binding for Mexican judges when it is more favorable for the protection of human rights than national interpretations, even in cases where the Mexican State has not been a party, because such interpretations determine the content of the human rights contemplated in the Inter-American Convention of Human Rights. ${ }^{52}$

\section{The Gurrent Use of Foreign Courts' Case Law by Mexican Courts}

Following the events described in Section II, at the present time, all judges must analyze the compatibility of national norms and the Inter-American Convention of Human Rights, its Protocols, and IACHR case law. ${ }^{53}$ Furthermore, the interpretations of the IACHR are considered binding for Mexican courts whenever they are more favorable to the person than domestic ones, regardless whether Mexico was a party in the dispute that generated the interpretation or not. ${ }^{54}$ Thus, judges are obliged to analyze and acknowledge the interpretations issued by both the Mexican Judiciary and the

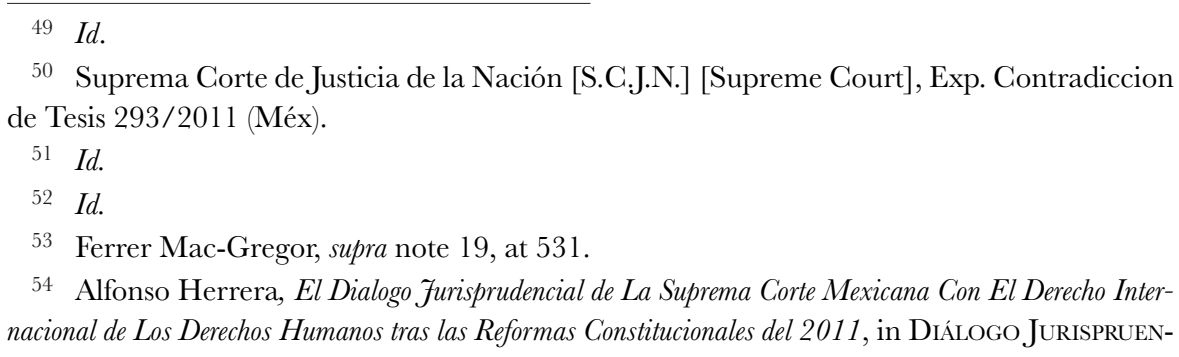


IACHR to weigh which one is more favorable and beneficial to the right that must be protected. 55

In this regard, the conventionality control introduced in Mexico, what is known as "transjudicial dialogue", 56 which essentially means the practice performed by domestic courts to incorporate the findings of foreign courts into their own decisions. ${ }^{57}$ However, I believe that the use of such dialogue has been quite limited, as judicial interpretations of human rights provisions in other jurisdictions have been ignored as a source of principles or standards in the interpretation of human rights.

Notwithstanding the fact that the pro persona principle mandates that judges must interpret human rights in the most favorable way possible and limitations of rights on the least restrictive manner, both the Mexican Constitution and the Supreme Court have only considered the conventionality control doctrine as a tool for judges to decide which interpretation should be applied as being more beneficial for the protection for rights. Judges must analyze whether to apply the interpretations issued by the Mexican Federal Judiciary or those dictated by the IACHR.

Even after the analysis made in the "Varios 912/2010" file on the meaning and scope of the pro persona principle, the Supreme Court also declared that, when confronted with multiple possibilities to resolve a human rights issue, the pro persona principle obliges judges to select the provision or interpretation that protects the rights in the broadest scope. ${ }^{58}$ Consequently, judges must employ the legal norm or interpretation that embodies the broadest protection, or the provision that least restricts the exercise of the right. ${ }^{59}$ Nevertheless, the Supreme Court has not declared anything regarding the possibility of Mexican courts to look beyond national and international in-

cial en Derechos Humanos entre Tribunales Constitucionales y Cortes InternacionaLES 874-875 (Eduardo Ferrer Mac-Gregor and Alfonso Herrera eds. Tirant lo Blanch) (2013).

55 Ibid. at 874-875.

56 Slaughter, supra note 12, at 524; Naomi Hart, Complementary protection and transjudicial dialogue: Global best practice or race to the bottom?, 28 International Journal of REFugee LaW 171 209, 172 (2016); Antje Wiener \& Philip Liste, Lost Without Translation? Cross-Referencing and a New Global Community of Courts, 21 Indiana Journal of Global Legal Studies 263, 267 (2014); Anne-Marie Slaughter, A Typology of Transjudicial Communication, 29 UnIversity of Richmond Law Review , 29 (1994); McCrudden, supra note 1, at 527.

57 Hart, supra note 56, at 172.

58 Principio pro PERSONAe. CONGRUENTE CON SU INTERPRETACión POR LA SUPREMA CORTE DE JUSTICIA DE LA NACIÓN Y LA CORTE INTERAMERICANA DE DERECHOS HUMANOS, EN LOS PROCEDIMIENTOS O JUICIOS EN LOS QUE, ADEMÁS DE LOS ENTES ESTATALES, ESTÉN INVOLUCRADAS PERSONAS (PARTES) CON INTERESES CONTRARIOS, DEBE APLICARSE VELANDO POR QUE TODOS LOS DERECHOS HUMANOS DE ÉSTAS SEAN RESPETADOS Y NO SOLAMENTE LOS DE QUIEN SOLICITA SU PROTECGIÓN. Primera Sala de la Suprema Corte de Justicia de la Nación [S.C.J.N.] [Supreme Court], Semanario Judicial de la Federación y su Gaceta, Décima Época, Libro V, Tomo 1, Febrero de 2012, Tesis 1a. XXVI/2012 (10a.), p. 659 (Mex.).

59 Id. 
terpretations of human rights to find the most favorable understanding and scope for their protection.

As a result, Mexican courts only have the legal obligation, as mandated in the constitution and interpreted by the Supreme Court, to rely on national case law and IACHR precedents to interpret human rights and making sure to apply the one that is more favorable and beneficial to the individual, thus exercising the conventionality control doctrine.

However, as the Chief Justice of the Norwegian Supreme Court pointed out: "it is the duty of national courts-and especially of the highest court in a small country-to introduce new legal ideas from the outside world into national judicial decisions". ${ }^{60}$ Thus, as I will argue hereunder, Mexican courts should consider foreign case law and precedents as persuasive authority to find the most protective or favorable interpretations of human rights.

\section{The Use of Foreign Human Rights Interpretations to Enforce the Pro Persona Principle}

I propose that, in order to enforce the pro persona principle in the best possible way, Mexican courts should take into account, as persuasive authority, foreign human rights law interpretations, engaging with them to analyze if they provide a more favorable understanding of human rights or a less restrictive limitation to such rights than binding domestic or international precedents, including IACHR case law. Indeed, by just applying the conventionality control, examining only national interpretations and IACHR case law, judges may be limiting the protection of human rights when there might be even more progressive views elsewhere.

Dworkin argues that in disputes about rights and obligations, lawyers "make use of standards that do not function as rules but operate differently as principles, policies, and other kinds of standards". ${ }^{61}$ Whereas policies set goals to be reached for the improvement in some economic, political, or social feature of the community, principles are standards to be observed because they are a requirement of justice, fairness or some other dimension of morality. ${ }^{62}$ Furthermore, principles are different from legal rules. Dworkin claims: "rules are applicable in an all-or-nothing fashion. If the facts a rule stipulates are given, then either the rule is valid, in which case the answer it supplies must be accepted, or it is not, in which case it contributes nothing to the decision". ${ }^{63}$ On the other hand, principles do not set out legal consequences that follow automatically when the conditions provided are met; they state a reason that

\footnotetext{
60 Anne-Marie Slaughter, A Global Community of Courts, 44 Harv. InT'L LJ 191, 195 (2003).

61 Ronald Dworkin, Taking Rights Seriously 22 (Gerald Duckworth \& Co Ltd., 1977).

62 Ibid. at 25.

63 Ibid. at 24.
} 
argues in one direction but does not necessitate a particular decision. ${ }^{64}$ Even though they might incline the court to consider them in its decision, principles must be weighted with other policies, principles, and standards. ${ }^{65}$

There is no formula to test how much or what kind of institutional support is necessary to make a principle a legal principle, but when arguing its value judges must confront it "with a whole set of shifting, evolving and interacting standards (themselves principles rather than rules) about institutional responsibility, statutory interpretation, the persuasive force of various sorts of precedent, the relation of all of these to contemporary moral practices and hosts of other such standards". ${ }^{66}$ Waldron believes that deep background principles, legal principles, may be inferred not from only one body of positive law, as Dworkin argued, but also from multiple systems together. ${ }^{67}$ According to Waldron, principles can be found in a whole array of legal systems, as "laws common to all mankind" or "ius gentium". 68

Furthermore, Waldron proposes that courts should adopt this global consensus not only because of its normative force, but because they can work as persuasive precedents; thus, courts are bound to take them into account and give them the appropriate weight, though not binding weight as their balance with other standards might incline courts to rule another way. ${ }^{69}$

The present analysis takes Waldron's claim concerning the sources where principles and standards to interpret human rights may be found. I propose that Mexican courts should also look for these principles in foreign courts' interpretations, not only in domestic and international law, as the conventionality control doctrine intends. However, unlike Waldron I do not believe they should do it to find if there is a ius gentium, but to explore if there is a more protective understanding of rights or a less restrictive comprehension of their limits, and consequently apply such interpretation, as the pro persona principle suggests.

Furthermore, similar to Waldron's theory, I propose that Mexican courts should cite foreign case law as a persuasive precedent or authority, engaging with principles and standards of human rights established by foreign courts, weighting them with relevant national and international principles and standards in each case.

There are two kinds of "authority" in judicial interpretation: "binding authority" and "persuasive authority". Binding authority refers to the sources of law that courts are legally obliged and bound to apply and follow. ${ }^{70}$ In con-

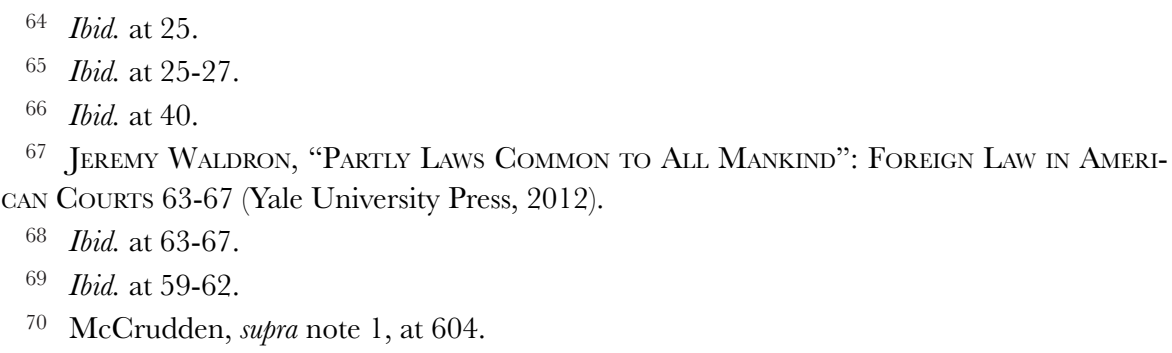


trast, persuasive authority refers to other material that might be relevant to the decision to be made by the court, but its application is not compulsory by the hierarchical rules of the national system. ${ }^{71}$ The use of persuasive authority gives those in charge of the application of law freedom in the choice of sources of law to be used, which may sometimes be the only real alternative to arbitrary conduct or could even be more effective than to follow binding, but unpersuasive, law. ${ }^{72}$

It is important to mention that there are three different positions towards using transnational precedents and law: resistance, convergence, and engagement. The resistance standpoint defends that only national legal provisions should be considered when interpreting law, while foreign and international law are rejected as sources of authority. ${ }^{73}$ The posture of convergence lies in the idea that national law should be identifiable with transnational and international provisions. ${ }^{74}$ Finally, the engagement point of view is founded on the belief that courts should deliberate either to harmonize or reject transnational provisions when interpreting domestic laws. ${ }^{75}$

Additionally, according to Vicki Jackson, there are two ways of engaging with foreign law, the deliberative and the relational models. ${ }^{76}$ In the deliberative model, foreign law and experience are used to examine national traditions and possibilities by analyzing the reflection of others, either to identify differences or reveal similarities, ${ }^{77}$ such as in the case of Lange $v$ Australian Broadcasting on defamation and political figures when the High Court of Australia rejected the US Supreme Court's approach in the case of the New York Times v Sullivan, because the Australian constitutional context was very different from the American one. ${ }^{78}$ On the other hand, the relational model includes a rational presumption in favor of considering international or foreign law, either because there is an explicit constitutional mandate to consider it, or because judges feel an obligation to acknowledge or apply it. ${ }^{79}$ A useful example is the Constitution of South Africa, which, in its Article 39, declares that when interpreting the Bill of Rights, courts, tribunals and forums must consider foreign and international law. ${ }^{80}$

71 Id.

72 H. Patrick Glenn, Persuasive Authority, 32 Revue de Droit de McGill 262-298, 263-264 (1987).

73 Vicki Jackson, Constitutional Engagement in a Transnational Era 8 (Oxford University Press, 2010).

74 Ibid. at 8.

75 Vicki Jackson, Constitutional Comparisons: Convergence, Resistance, Engagement, 119 HarvarD

Law Review 109-128, 9 (2005).

76 JACKson, supra note 73 , at 72.

77 Ibid. at 73-77.

78 Lange $v$. Australian Broadcasting Corporation (1997) 189 CLR 520 (Australia).

79 Jackson, supra note 76, at 77-78.

80 Article 9 (1) (c) of the South African Constitution, 1996. 
Whereas Mexican courts must apply the relational model to consider international human rights law and IACHR case law when they are more beneficial to the individual than domestic law, according to the Supreme Court's interpretation of Articles 1 and 133 of the Constitution, I propose that they should use the deliberative mode of engagement with foreign courts interpretations of human rights. Consequently, when interpreting human rights Mexican courts should not only apply the conventionality control, i.e., choosing only between domestic interpretations or IACHR case law to find the most beneficial understanding of rights; they should also acknowledge foreign decisions as persuasive authority.

The IACHR has mentioned that the most favorable protection must be chosen if doing so does not alter the country's legal system. ${ }^{81}$ Consequently, foreign courts' interpretations should not be considered binding; even if they are the most protective, they should always be weighted with relevant national and international principles and standards.

That said, the use of foreign courts' human rights case law by Mexican courts in order to apply the most favorable understanding and protection of rights is not incompatible with the current understanding of human rights and their interpretation in Mexico. As former IACHR president Eduardo Ferrer Mac-Gregor has claimed, the IACHR interpretations are a "minimum standard" for national judges, which should be followed but can be set aside when there is a more protective interpretation. ${ }^{82}$ Thus, the conventionality control can be expanded by other national, international, and foreign interpretations.

Likewise, Gerald Neuman argues that the "saving clauses" or "favorable to the individual" clauses (such as the one contained in Article 1 of the Mexican Constitution and Article 29 of the American Convention) "are intended to ensure that international protection operates as a floor, not as a ceiling, for human rights" ${ }^{83}$ Hence, if the most protective or favorable interpretation is found in a foreign precedent, Mexican courts should consider it as persuasive authority when interpreting human rights.

Slaughter claims that municipal institutions in liberal democratic States, in particular domestic courts, rather than international institutions, are the reason why a "new transnational legal order" is being constructed and enforced. ${ }^{84}$ Further, human rights conflicts are discussed much sooner before domestic courts than before international courts, such as the IACHR.

81 Viviana Gallardo v. Costa Rica, 1981 Inter-Am. Ct.H.R. (Ser A) No. G 101/81, at 16 (June 30, 1983).

82 Ferrer Mac-Gregor, supra note 19, at 395.

83 Gerald L. Neuman, Human Rights and Constitutional Rights: Harmony and Dissonance, 55 STANFORD LAW REVIEW 1863-1900, 1886 (2003).

84 Slaughter as cited in: Alex Mills \& Tim Stephens, Challenging the Role of Fudges in Slaughter's Liberal Theory of International Law, 18 LeIDEN Journal of INTERNATIONAL LaW 1-30, 2 (2005). 
Hence, foreign courts might have a progressive understanding of the scope of protection of a certain right that has not even been discussed by the IACHR.

In this regard, Mexican courts should engage with such foreign courts' standards of protection when analyzing human rights issues in order to help them determine the most protective or least restrictive interpretation, as the pro persona principle suggests.

As Fredman argues, in disputed human rights cases there may not be only one right answer, but the concern that judges will impose their own subjective beliefs and values can be overcome by an analysis that is persuasive and balances a variety of alternative solutions, for which comparative materials are a significant contribution. ${ }^{85}$ If courts in other jurisdictions have faced similar human rights problems and have already discussed and weighed the arguments in different directions, these should be taken into account by Mexican courts as part of their decision-making process. ${ }^{86}$

\section{Reasons to Gonsider Foreign Case Law as Persuasive Authority}

There have been different reasons to support the use and citation of foreign precedents in deciding the scope, content, and limits of human rights. However, not all of them are convincing reasons to rely on foreign case law when trying to look for principles that provide standards about the most protective or least restrictive interpretation of human rights, as the pro persona principle suggests. In this section I will analyze each of these reasons.

\section{Universalism}

One reason for using foreign human rights law interpretations is based on the theory that human rights are universal, ${ }^{87}$ meaning that all constitutional courts are figuring out how to identify, interpret, and apply the same set of provisions that are transcendent legal principles and have existed before positive rules of law and legal doctrines. ${ }^{88}$ Consequently, judges should harmonize these universal values when interpreting human rights because of their "supra-positive" aspect. 89 As Posner has argued, "citing foreign deci-

85 Sandra Fredman, Foreign Fads or Fashions? the Role of Comparativism in Human Rights Law, 64 International and Comparative LaW Quarterly 631-660, 634 (2015).

86 Ibid. at 641 .

87 Ibid. at 636.

88 Sujit Choudhry, Globalization in Search of Fustification: Toward a Theory of Comparative Constitutional Interpretation, 74 INDIANA LAW JournaL 819-892, 825 (1999).

89 Neuman, supra note 83, at 1868. 
sions as precedents is to flirt with the idea of universal natural law or to suppose fantastically that the world's judges constitute a single, elite community of wisdom and conscience". 90

However, accepting the universalism theory is to assume that there is only one right answer to human rights issues and their interpretation, which is not possible as there is little, if any, consensus worldwide, or even within societies, as to which rights are considered human rights, as well as what their content, scope, limits, and interpretation are. As Fredman claims, even if there were universal human rights values, it would still be necessary to determine their application to the local context of each jurisdiction. ${ }^{91}$ Thus, it is unlikely that we will find universal answers to decide how human rights must be balanced, limited, and weighed with other conflicting rights. ${ }^{92}$

Consequently, to affirm that Mexican courts should apply a particular foreign case law, when trying to find the most beneficial interpretation of a right, as demanded by the pro persona principle by claiming that such interpretation is a universal standard would be a flawed and unfounded argument. Foreign judgments are not cited because they lay down a discovered truth or a higher law, but rather because courts in other jurisdictions have struggled with the same conflicting principles. ${ }^{93}$

Nevertheless, universalist arguments need not be so profoundly skeptical and dismissing them solely because they have been equated to natural law theory would be precipitated. ${ }^{94}$ Certainly, the law is not merely a body of rules, but a body of principles that are not inherently limited to a particular society. ${ }^{95}$ Thus, if the same kind of problems arise in different legal systems and are resolved similarly, as Choudhry argues, a foundation for the grammar and theoretical concepts of a universal legal language can eventually emerge. ${ }^{96}$

In that case, if the solutions proposed by different legal systems regarding human rights have gained global recognition and are more progressive than national or international case law, Mexican courts should then apply such standards when deciding similar human rights cases. Comparative case law can offer a convenient shortcut to attaining the same goal, protecting the individual against human rights violations. ${ }^{97}$

90 Richard A. Posner, A Political Court, 19 Harvard Law Review 31-102, $86-87$ (2005).

91 Fredman, supra note 85, at 637.

$92 \mathrm{Id}$.

93 McCrudden, supra note 1, at 528.

94 Michael Elliot, Rethinking the Use of Foreign Law in Adjudicating Rights Claims : Paying Heed to the Importance of Analytical Methodology, 30 National Journal of Constitutional LaW 107-146, 117 (2012); Choudhry, supra note 88, at 825.

95 Elliot, supra note 94, at 117.

96 Choudhry, supra note 88, at 834.

97 Ibid. at 835. 


\section{Fairness}

Fairness (treating like cases in the same way) is one of the typical reasons for courts to apply national judicial precedents or case law. ${ }^{98}$ Therefore, one might argue that applying standards that have been already discussed and accepted by foreign courts would be the fair thing to do.

Bronaugh discusses that it is unclear why precedents should only be followed when similar cases have been resolved within a particular jurisdiction, being that relevant similarities can also be obtained from across national borders. ${ }^{99} \mathrm{He}$ believes that following a precedent that derives from a foreign court can lead us to a fair outcome and to not follow it can result in an unfair decision, as one cannot "say that the «same things» never happen in other legal systems". ${ }^{100}$

However, as McCrudeen explains, we cannot justify the appropriateness of citing foreign precedents as persuasive authority only because of the similarity of the cases, especially since for the principle of "fairness" to operate, the judge must have an obligation to treat those similar cases in the same way. ${ }^{101}$

Mexican courts have the legal duty to solve similar cases in the same sense, as well as to apply the case law of higher court cases that are alike, respecting the principle of "legal certainty" and "fairness". However, as I previously argued, the pro persona principle does order Mexican courts to look for the most protective and beneficial interpretation of human rights. Consequently, if a foreign court has already issued a more progressive interpretation than those that are binding to Mexican courts in a similar human rights case, it would certainly be fair to apply it, not because courts should treat cases in the same manner foreign courts do, but because the standard of protection is higher than the one available in the binding sources of authority.

\section{Ius Gentium}

Waldron defines ius gentium as "a body of law purporting to represent what various domestic legal systems share in the way of common answers to common problems". ${ }^{102}$ As previously discussed, Waldron believes that some legal principles can be found in multiple legal systems taken together, thus their presence in these different legal systems will mean that they are "laws com-

\footnotetext{
98 McCrudden, supra note 1, at 513.

99 Bronaugh as cited in McCrudden, supra note 1, at 513.

100 McCrudden, supra note 1, at 513.

$101 \mathrm{Id}$.

102 Jeremy Waldron, Foreign Law and The Modern Ius Gentium, 119 Harvard Law Review 129147, 133 (2005).
} 
mon to all mankind." 103 However, this ius gentium does not derive from natural law, but from reaching the same legal answer to similar legal problems. ${ }^{104}$

Consequently, courts should behave towards this transnational consensus the same way health authorities would deal with a new disease, looking abroad to see what scientific conclusions and strategies have emerged, have been tested, and have been mutually validated in other countries. ${ }^{105}$

However, Waldron's theory has been opposed by critics such as Fredman, who argued that the view of ius gentium might be problematic as there is not a well-defined set of commonly shared principles. ${ }^{106}$ Nonetheless, as Waldron claims, ius gentium should be considered as a persuasive precedent; thus, the court must take it into account and give it appropriate weight even if it rules differently. ${ }^{107}$

I believe that if various domestic legal systems share a common answer to a common problem or an ius gentium, Mexican courts should give it the appropriate weight when deciding on human right cases. Nonetheless, the pro persona principle would require them to apply it only if it is a more favorable interpretation or provides a less restrictive standard than the ones established by domestic courts or the IACHR.

\section{A Global Framework}

Slaughter argues that judges of liberal democracies should participate in a transnational process to articulate provisions for other judges to enforce. ${ }^{108}$ She believes that a global set of human rights should be framed by the collective judicial deliberation among national courts through the acknowledgment and use of each other's decisions. ${ }^{109}$ In consequence, such transjudicial communication would lead to an emerging "global jurisprudence" created by a "global community of courts". 110

Slaughter's account has been criticized because it assumes that courts of liberal democratic States operate systematically and that there is homogeneity among liberal regimes, being that although they may share some principles such as the separation of powers, judicial independence, and impartiality, they are also very different in several ways. ${ }^{11}$ Furthermore, not all courts have welcomed the use of foreign law and interpretations, and they should be careful

\footnotetext{
103 WALDRON, supra note 67, at 63-67.

104 Waldron, supra note 102, at 143-145.

105 Ibid. at 143.

106 Fredman, supra note 85, at 640.

107 WALDRON, supra note 67, at 61-62.

108 Slaughter, supra note 56, at 121-122.

109 Id.

110 Slaughter, supra note 60, at 202.

111 Mills \& Stephens, supra note 84, at 21.
} 
when considering its applicability in each case since a legal model that has succeeded in one jurisdiction might not work in a different legal environment. ${ }^{112}$

In this regard, Mexican courts should take part of this transnational judicial dialogue of human rights, not only exercising the conventionality control, but also considering precedents from foreign courts. Nevertheless, they should not do it under the presumption that they must converge with foreign interpretations because of the idea of a global case law about a particular human rights-related standard. Instead, they should measure domestic practices and IACHR case law with foreign precedents to evaluate if they are actually more beneficial to the individual, engaging with such interpretations and principles to define whether it is appropriate to apply them in a particular case, recognizing the values, ideals, principles, practices, and institutions important to Mexican society.

\section{Persuasiveness or Legitimacy}

Another reason to rely on foreign case law to interpret human rights is based on the view that judgments will have greater legitimacy. ${ }^{113}$ Slaughter has pointed out that courts might borrow an idea or a legal solution from a foreign decision if they believe it will strengthen their decision. ${ }^{114}$ Judges want to be acknowledged for doing a "good job", thus, they might cite a foreign case because it contributes to convincing their audience of the appropriateness of their decision. ${ }^{115}$

While foreign constitutional court decisions may be helpful in the most controversial choices and offer hope of greater impartiality, the legitimacy of looking to foreign experience will vary depending on the issue. ${ }^{116}$ A legitimate legal argument requires the wise use of these foreign sources, including acknowledging the context of the decision and recognizing differences of opinion. ${ }^{117}$ Courts must be aware that constitutional democracies have quite different approaches to abortion, hate speech, criminal procedure, and public support for religion. ${ }^{118}$ However, this does not mean they should not look at foreign judgments to resolve the cases upon them, but simply that it requires an issue-by-issue, as well as a thoughtful and well-informed, analysis. ${ }^{119}$

In this sense, Mexican courts must be cautious when comparing cases using a foreign understanding of human rights when looking for the most pro-

\footnotetext{
112 Fredman, supra note 85, at 639.

113 JACKSON, supra note 73, at 46.

114 Slaughter, supra note 56, at 119.

115 McCrudden, supra note 1.

116 Jackson, supra note 75.

117 Ibid. at 126 .

118 Ibid. at 128 .

119 Ibid. at 128.
} 
tective interpretation. The persuasiveness of their arguments and legitimacy of their decision will also depend on the analysis of the context of the foreign decision and its applicability to the case.

\section{Text Similarities}

An additional motive for using foreign interpretations follows the presumption that legal texts share the same meaning and autonomy. Especially since constitutional ideas were not developed on their own, constitutions have been designed and influenced by each other. ${ }^{120}$ Furthermore, bills of rights have been inspired by human rights covenants; consequently, it can be assumed that a transnational consensus regarding human rights might be reached, as nations commit themselves to a shared set of principles, values, and aspirations. ${ }^{121}$ Hence, interpretations issued by other courts could be beneficial. ${ }^{122}$

Mexican courts should indeed look into how foreign courts have interpreted similar legal texts regarding human rights provisions. Nonetheless, they should not take their considerations only because of similarities between texts, but because they offer a more extensive understanding of such human rights provisions than those reached by national courts or the IACHR.

\section{Law as an Inquiry}

Another posture of engagement is viewing law as a form of inquiry. ${ }^{123}$ This position is supported by Patrick Glenn and it proposes to embrace the use of non-binding and non-national sources of law in order to reach better ways of interpreting national law and enhancing judicial self-awareness. ${ }^{124}$ Glenn believes that legal officers are free to use extra-national sources as persuasive authority. ${ }^{125}$ He further explains that "the extent that the law used by these officers is not definitely made and imposed upon them but is rather chosen by them in an ongoing process, the underlying notion of law is that of enquiry". 126

Consequently, in their process to find and determine which is the most protective interpretation of a right or the least restrictive limitation, Mexican courts should adopt Glenn's view and consider non-binding and non-national sources of law in order to reach better ways to decide human rights cases.

\footnotetext{
${ }^{120}$ JACKsOn, supra note 73, at 52

$121 \mathrm{Id}$.

122 Id.

123 Ibid. at 82.

124 Jackson, supra note 73; Glenn, supra note 72.

125 JACKsON, supra note 73, at 82; Glenn, supra note 72, at 288.

126 JACKsOn, supra note 73, at 82; Glenn, supra note 72, at 288.
} 


\section{Constitutional Law as Mediating the Domestic and the Global}

Engaging with foreign interpretations might also be considered helpful because constitutions serve as mediating institutions between national and global scopes. Even though they are created for a particular polity, their texts do not only include domestic necessities, but they also take into consideration international expectations, incentives, and relationships. ${ }^{127}$ Consequently, if constitutions harmonize the internal polity of a nation with other national States, courts might feel an obligation to consider foreign constitutional law and international law. ${ }^{128}$

As I have stated, according to the Mexican Supreme Court, Mexican courts do have an obligation to consider international law as Articles 1 and 133 of the Mexican Constitution mandates them to do so. However, this is not the case with foreign law. The use of foreign precedents as persuasive authority must not emanate from wanting to mediate with the global aspects, but because they can find good reasons to apply a foreign interpretation for being more progressive than national case law or IACHR interpretations.

\section{Pedagogical Impulse and Pragmatism}

Claire L'Heureux-Dube noted that "human rights issues like assisted suicide, abortion, hate speech, gay and lesbian rights, environmental protection, privacy, and the nature of democracy are being placed before judges in other jurisdictions at approximately the same time". ${ }^{129}$ Consequently, courts might have the pedagogical impulse to look abroad merely because it helps them do a better job, in the sense that they can resolve the cases upon them more creatively or with greater insight, as foreign decision can provide a broader range of ideas and experiences, as well as better and more reflective views. ${ }^{130}$

Indeed, judges must be pragmatic and must look to make the best judgment bearing all factors in mind. ${ }^{131}$ Thus, they must benefit from considering world public opinion and foreign laws and practices as facts, which can be a more profitable inquiry than trying to find some evidence of what the framers of the Constitution wanted courts to understand. ${ }^{132}$

As Choudhry has pointed out, "comparative jurisprudence can be an important stimulus to legal self-reflection". ${ }^{133}$ Foreign interpretations can help

\footnotetext{
127 JACKSON, supra note 73, at 85.

128 Ibid. at 85-86.

129 Claire L'Heureux-Dube, The Importance of Dialogue: Globalization and the International Impact of the Rehnquist Court, 34 Tulsa Law Review 15-40, 23 (1998).

130 Slaughter, supra note 60, at 201.

131 Richard A. Posner, Pragmatic Adjudication, 18 Cardozo Law Review 1-20, 13-14 (1996).

132 Ibid. at 13-14

133 Choudhry, supra note 88, at 836.
} 
national courts understand their own constitutional systems and case law. ${ }^{134}$ Moreover, not all constitutional courts have a long history exercising their role as human rights protectors; hence, there might be little or no domestic case law to consult from when interpreting a particular issue. ${ }^{135}$ Consequently, judgments from elsewhere can be useful to develop human rights case law and to fill in gaps when no precedent exists. ${ }^{136}$

Mexican courts should indeed feel a pedagogical impulse to engage with foreign courts' decisions to be pragmatic and find the most favorable or least restrictive standard when deciding about human rights issues. Therefore, they should take into account more creative or greater insights than those available within national boundaries or issued by the IACHR, which would give them a broader range of ideas and experiences that can result in a better and more reflective understanding of rights.

This is even more relevant since Mexican courts have just recently engaged in the interpretation of human rights and began to exercise their role as human right's protectors, foreign experiences can be a worthy persuasive source for the understanding of human rights and their scope.

\section{Existence of Common Alliances}

McCrudden has identified that a deliberate "alliance" appears to be one reason for citing foreign sources in human rights cases, as courts might use judicial judgements from particular jurisdictions because they believe their decisions are part of a larger project of economic or social integration, or a continuation of a shared history. ${ }^{137}$ Likewise, Choudhry has argued that "genealogical relationships" between countries are essential when borrowing and lending interpretations because where there is no historical relationship comparative legal study is not appropriate. ${ }^{138}$ On the other hand, Choudhry believes that "genealogical relationships" justify the importation and application of entire areas of constitutional doctrine, and that they confer sufficient authority and validity. ${ }^{139}$

The European Court of Human Rights has held that, although the countries under its jurisdiction have a "margin of appreciation" in determining what is "necessary in a democratic society", when a substantial number of other European States which are parties to the Convention have interpreted rights differently, the State's burden of justification will be higher. ${ }^{140}$ In the Dudgeon

\footnotetext{
134 Id.

135 L'Heureux-Dube, supra note 129, at 23.

136 Id.

137 McCrudden, supra note 1, at 521.

138 Choudhry, supra note 88, at 839.

139 Ibid. at 825.

140 McCrudden, supra note 1, at 522.
} 
case, the Court considered that the criminalization of acts of sodomy in Northern Ireland was not "necessary in a democratic society", partly because the majority of European countries have decided to decriminalize sodomy. ${ }^{141}$

Through the conventionality control doctrine, the IACHR aims for the countries under its jurisdiction to create a common understanding of the American Convention of Human Rights. Furthermore, several authors have referred to an emerging "Ius Constitutionale Commune in Latin America". ${ }^{142}$ However, Mexican courts should not limit their scope to Latin American countries, as other democratic States elsewhere might have progressive interpretations about human rights and their purview.

Still, courts do need to consider the political and social realities, values, and traditions of the country where the decision was made. ${ }^{143}$ Especially since human rights issues are very different between developed and developing countries, ${ }^{144}$ and Mexico being a developing country might need a different solution to a specific problem than a country such as the U.K. might. This does not mean that it is not helpful to look to foreign courts' interpretations because the context of their decision might be different; but simply that courts should deliberate whether if it is appropriate or not in each case. ${ }^{145}$

\section{Responding to Counterarguments}

The use of comparative case law raises difficult theoretical questions and critics, which arise from the differences between legal systems and other kinds of concerns. Next, I will respond to all these counterarguments.

\section{Constitutions are Self-Constituting and Self-Expressive}

One source of reasoning against foreign and international law is the idea that constitutions may be conceived as serving what Mark Tushnet called an "expressivist" role, which embodies a national identity and self-understanding. ${ }^{146}$ Furthermore, under this view, constitutions are designed to sustain or respond to a nation's particular history and political traditions. ${ }^{147}$ Hence, the legal par-

\footnotetext{
141 Id. Dudgeon v. UK 4 Eur. Ct. H.R. 149 (1981).
}

142 Armin von Bogdandy, Eduardo Ferrer Mac-Gregor, Mariela Morales Antoniazzi, Flávia Piovesan, Ximena Soley, Ius Constitutionale Commune en América Latina: A Regional Approach to Transformative Constitutionalism, in Transformative Constitutionalism in Latin America: The Emergence of a New Ius Commune 464 (Oxford Constitutional Law, 2017).

143 L'Heureux-Dube, supra note 129, at 26.

144 Id.

145 Id.

146 Tushnet cited in: Jackson, supra note 73, at 18.

147 Ibid. at 20. 
ticularism of one's own system serves as a barrier to use comparative case law because the differences between legal systems can really be profound and a comparison would be an inappropriate tool to understand one's own system. ${ }^{148}$

Nonetheless, with the constitutional reform of 2011, Mexico opened up to transnational influence, at least regarding international human rights and IACHR case law. Thus, there is not a strong resistance to transnational dialogue to help reach protective human rights standards. On the contrary, the mentioned amendment shows that one of Mexico's national commitments is towards the progressive protection of human rights in the country.

Furthermore, cases such as the one known as "Pabellón 13" serve as examples of the open position Mexico has towards transnational human rights and progressive standards. In the 2014 Pabellón 13 case, after resolving that Mexican authorities had failed to fulfill their obligation to ensure the health of HIV patients under the terms of Article 4 of the Constitution and Articles 2 and 12 of International Covenant on Economic, Social and Cultural Rights, as well as to take into consideration the standards on the right to health the Committee on Economic, Social and Cultural Rights had set in several opinions, the Supreme Court of Mexico ordered the authorities to provide HIV patients with adequate treatment, either by remodeling a section of the clinic or by building a new hospitality wing. ${ }^{149}$

Consequently, conceiving the Mexican Constitution as a self-expressive or self-constructing is not a convincing counterargument to stop courts from engaging with foreign case law to find the most protective or least restrictive interpretation of human rights in order to apply the pro persona principle.

\section{Originalism and Popular Sovereignty}

Jackson has also noted that resistance to foreign interpretations regarding national law, including human rights, is associated with the idea that constitutions must be interpreted by looking for the original meaning of the moment when its text was adopted, as well as the intention of its framers. ${ }^{150}$ Consequently, importing foreign interpretations has been considered to be inconsistent with self-governing; thus they should be interpreted in the way that they were consented to, in the time and context in which they were democratically adopted. ${ }^{151}$

These ideas rest on the assumption that constitutions are legitimate when they are accepted consensually by a society. ${ }^{152}$ Consequently, foreign and in-

\footnotetext{
148 Choudhry, supra note 88, at 835.

149 Suprema Corte de Justicia de la Nación [S.C.J.N.] [Supreme Court], Exp. Amparo en Revision $378 / 2014$ (Méx).

150 JACKSON, supra note 73, at 20.

151 Ibid. at 21.

152 Ibid. at 22.
} 
ternational law can be considered when it is consistent with the original understanding of the constitution agreed upon by the popular sovereignty. ${ }^{153}$

No provision in the Mexican Constitution mandates that courts are bound to interpret rights according to the original intention of the drafters. On the contrary, Article 1, as interpreted by the Supreme Court, instructs authorities to interpret human rights by relying not only on the Constitution but to also consider international human rights treaties and IACHR case law, always choosing the most favorable understanding.

Consequently, there is no reason to question Mexican courts' use of foreign case law arguing that the interpretation of human rights in Mexico is committed to the original intention of its constitution's framers. Foreign sources can undoubtedly be used to develop human rights understanding and their scope of protection in a more favorable way. ${ }^{154}$

\section{It is Anti-democratic}

Professor Roger Alford argued that using foreign interpretations can threaten "majoritarian" approaches to constitutional interpretation, which do not refer to the original meaning intended by the framers, but contemplates positions that may defer to legislative or executive decisions, who are elected by popular majorities and hence reflect their will. ${ }^{155}$ Under this view, the understating or interpretation of the constitution may evolve, but will depend on the will and views of the contemporary majorities. ${ }^{156}$

Consequently, comparative human rights law is seen as anti-democratic, as foreign courts and legal systems have no democratic accountability in the national legal system. ${ }^{157}$ Elliot has held that regardless of whether or not judicial review is democratic, the decisions of foreign judges and legislatures are decidedly not, because despite how domestic judges are appointed, they are at least within the "democratic orbit" of a particular society, while foreign lawmakers and courts exist outside of it. ${ }^{158}$

However, engaging with foreign legal materials with a deliberative approach does not mean that they should have the same authority as domestic law; courts should only apply them as far as they improve their judicial reasoning. ${ }^{159}$ As Jackson has pointed out, majorities might find the foreign experience useful, and other societies might also share a commitment to ma-

\footnotetext{
153 Id.

154 Ibid. at 80.

155 Alford cited in Jackson, supra note 73, at 23.

156 Id.

157 Fredman, supra note 85, at 649.

158 Elliot, supra note 94, at 115.

159 Fredman, supra note 85, at 650.
} 
joritarianism and the judicial protection of rights. ${ }^{160}$ Thus, how their constitutional courts resolve challenges regarding human rights violations can be not only helpful but can also be relevant. ${ }^{161}$

Judges are accountable through the explanations they provide for their decisions; hence, if foreign materials improve the quality of their reasoning process, this will legitimize the application of such sources of law as persuasive authority. ${ }^{162}$ Indeed, it is not through the express authorization of the citizens or the constitutional texts that judges derive their legitimacy in referring to foreign sources, but through the persuasiveness of their reasoning and arguments given. ${ }^{163}$

As an example, we could look at the judgment where the Mexican Supreme Court relied on US, Uruguayan and Dutch laws on cannabis control and use in order to test whether the General Health Law was unconstitutional for establishing an absolute prohibition on the use of cannabis, including for recreational purposes. The Supreme Court showed that other countries have less restrictive prohibitions, and therefore, the absolute prohibition contained in the General Health Law was not a proportional restriction and subsequently violated the rights to the free development of the personality. ${ }^{164}$

Consequently, if the reasons for Mexican courts to rely on foreign case law when interpreting the scope of protection of human rights are persuasive mainly because they are more protective or less restrictive than binding national or international interpretations, their decisions will be legitimized by enforcing with the pro persona principle in the best possible way.

\section{Cherry-picking}

One of the most significant concerns about using foreign interpretations is that judges must be constrained from using these interpretations to legitimize their own preferences. Posner said, "if foreign decisions are freely citable, any judge wanting a supporting citation has only to troll deeply enough in the world's corpora juris to find it." 165 Moreover, Young argues that citing foreign case law when interpreting constitutional rights can generate decision and error costs to courts, including what he calls "indeterminacy costs", which arise from the great variety of foreign jurisdictions and sources of interna-

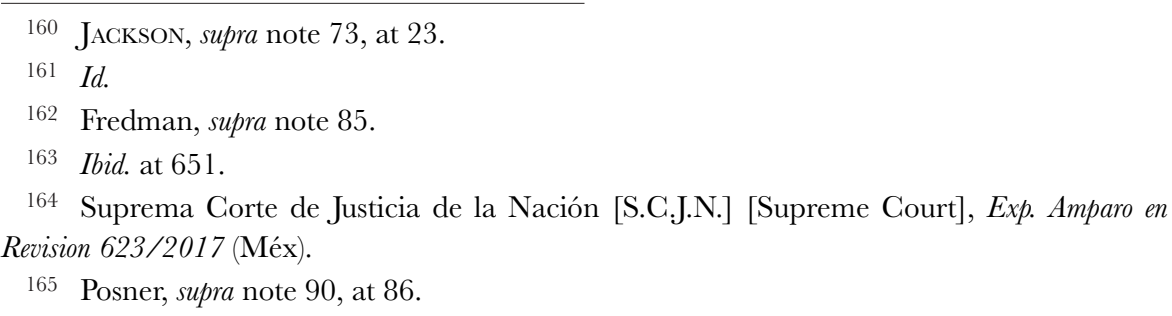


tional law, which are often so ambiguous that the whole enterprise can be profoundly manipulable. ${ }^{166}$

Antonin Scalia, a former Justice of the Supreme Court of the United States, also argued against using foreign law to interpret domestic rights. For him, the citation of foreign law is a pretext judicial elites use to impose their own moral and social views, subjective values, and thinking. ${ }^{167}$

Nonetheless, the purpose of Mexican courts' use of foreign case law is to apply the most progressive interpretation and scope of human rights, as intended by the pro persona principle. Far from being able to impose their own predetermined judgment, courts must use foreign case law as persuasive authority to interpret human rights scope of protection in the broadest way possible. Thus, there is no room for personal moral value; courts must base their choice within the extent to which a particular interpretation widens or limits the scope of protection of the human right at hand.

\section{Lack of Understanding}

Another concern about relying on foreign law to interpret domestic cases lies in the judges' limitations regarding their competence, understanding, training, and expertise on international or foreign law. ${ }^{168}$ According to Young, courts dealing with foreign materials face language and cultural barriers, as well as training in comparative analysis which could lead to unacceptable error costs. ${ }^{169}$

Furthermore, the foreign context and constitutional system may be different; thus, the lack of knowledge about the technical legal aspects of other jurisdictions could lead to mistakes when using foreign cases as persuasive authority. ${ }^{170}$ Consequently, the use of comparative materials requires knowledge not only of the foreign law, but also of the country's social and political context. ${ }^{171}$

Undoubtedly Mexican courts would be challenged in the face of all the difficulties described. However, Article 14 of the Federal Civil Code indicates that when applying foreign law, judges must apply it as the foreign court would. Hence, judges can collect all the information necessary about the text,

166 Ernest A. Young, Foreign Law And The Denominator Problem, 119 HaRv. InT'L LJ 148-168, 167 (2005).

167 Norman Dorsen, The relevance of foreign legal materials in U.S. constitutional cases: A conversation between Fustice Antonin Scalia and Justice Stephen Breyer, 3 International Journal of ConstituTIONAL LAW 519-541, 540-541 (2005).

168 Young, supra note 166, at 166.

169 Id.

170 McCrudden, supra note 1 , at 527.

171 O Kahn-Freund, On Uses and Misuses of Comparative Law (1974), 37 The Modern Law REVIEW 27. 
meaning, and scope of said law. ${ }^{172}$ This could also be implemented when interpreting human rights as judges can analyze the context of foreign decisions. As Elliot argues, the difficulties of understanding the context of foreign decisions need not be understood to deny the relevance of comparative analysis altogether, but simply to challenge the notion that courts are capable of engaging with it in such a way as to preclude misunderstandings. ${ }^{173}$

\section{Cultural Elites}

Another source of resistance is based on the perception that foreign or international law may be used by self-interested cultural elites to remake national policies in opposition to democratic decisions by ruling cases. ${ }^{174}$ Further, opposition to the consideration of the transnational also relies on the fear that the disadvantaged and marginalized, as well as collective rights and groups, might be ignored in favor of individual rights. ${ }^{175}$

However, I propose that Mexican courts engage with foreign case law to find the most protective interpretation of human rights and their scope. Hence, they cannot simply cite and choose foreign decisions over binding interpretations without them being more progressive and weighted with other standards. Therefore, courts cannot manipulate foreign case law to benefit certain groups or individuals because the reason for its adoption must be its benefits in understanding human rights.

Nonetheless, it is also certainly necessary to increase mechanisms to effectively protect the excluded. ${ }^{176}$ In any event, ignoring the problem of participation, while at the same time refusing to engage in the human rights dialogue with foreign judges, may weaken human rights protection rather than reinforce it, ${ }^{177}$ which runs in counter to the purpose of the pro persona principle.

\section{Conclusion}

Mexican courts should adopt a posture of engagement in a deliberative manner with foreign courts' interpretations of human rights, honoring the pro persona principle commitment foreseen in Article 1 of the Constitution. Consequently, when deciding the most favorable way to interpret human rights

172 Código Civil Federal [C.C.F.] [Federal Civil] as amended, Diario Oficial de la Federación [D.O.F], 26 de mayo, 14 de julio, 3 y 31 de agosto de 1928 (Mex.).

173 Elliot, supra note 94 , at 114.

174 JaCKSON, supra note 73, at 30.

175 Ibid. at 29.

176 Ibid. 531-532.

177 Ibid. at 531-532. 
and the least restrictive way to limit them, they should not only rely on the conventionality control doctrine.

Indeed, Mexican courts should also look for principles and standards in other legal systems rather than just domestic precedents and international sources, such as the case law of the IACHR. Foreign decisions can assist them in their role of human rights guarantors by providing them with progressive interpretations of human rights.

Nonetheless, not all the conclusions reached by foreign courts must be followed. Comparative materials should not be considered binding; they should only be acknowledged as persuasive authority. Consequently, courts can diverge from them, even when they are more beneficial to human rights understanding, as the weight of other principles, policies or standards in the Mexican legal system can persuade courts to decide in a different sense, especially if a foreign decision alters said legal system. Nonetheless, this does not mean that foreign precedents should not be part of the process of their decision.

Mexican courts should not engage with foreign interpretation about human rights because human rights are universal principles or a part of ius gentium. Nor because Mexican courts should become part of a "Latin American alliance" or a "global community of courts" that will contribute to "global jurisprudence" on the meaning and scope of human rights. Nor is it the case that these foreign precedents will legitimize their decision just by randomly citing them or because they interpret a similar text to the one, they need to clarify.

Mexican courts should look to foreign courts' case law regarding human rights because they might have already weighted principles and other standards in order to decide the best way to protect human rights, thus their conclusions can provide further tools for judges than those determined by domestic courts or the IACHR. This will then lead them to a more beneficial appreciation or a less restrictive limitation of rights.

The concerns about using foreign precedent are overcome with the understanding that Mexican courts will engage with them to exploit the pro persona principle, looking for the most protective standard or least restrictive limitation of rights in different legal systems. Consequently, courts must not use foreign decisions to impose preferences or to benefit specific groups, the weight of their applicability and appropriateness will depend directly on the capability of the foreign judgment to protect human rights better than domestic sources or international standards, such as the ones issued by the IACHR. This approach to the interpretation of human rights in Mexico is not inconsistent with its current legal system, as it has already opened to the transnational influence to advance in the protection of human rights by adopting the conventionality control. Nonetheless, engaging with more foreign sources might just help take the protection of human rights a little step further. 